\title{
円管内オリフィス下流における流れの再付着位置と熱伝達極大位置の関係
}

\author{
椎原 尚輝*1, 中村 元 $^{* 2}$, 山田 俊輔 ${ }^{* 2}$
}

\section{Relation between the positions of flow reattachment and maximum heat transfer at downstream of an orifice in a pipe}

\author{
Naoki SHIIBARA ${ }^{* 1}$, Hajime NAKAMURA ${ }^{* 2}$ and Shunsuke YAMADA*2 \\ ${ }^{*_{1},{ }^{* 2}}$ Department of Mechanical Engineering, National Defense Academy \\ 1-10-20 Hashirimizu, Yokosuka-shi, Kanagawa 239-8686, Japan
}

Received 29 February 2016

\begin{abstract}
The aim of the present study is to investigate the relation between the positions of flow reattachment and maximum heat transfer at flow reattachment region. Flow separation and reattachment at downstream of an orifice (bore ratio $d / D \approx 0.5, R e_{D}$ $\approx 13000$ ) in a pipe was chosen as a flow field. A technique using high-speed infrared thermography was used to measure the spatio-temporal heat transfer to a turbulent water pipe flow around an orifice. In this work, we attempted to evaluate the convection velocity of the heat transfer structure on the heated surface, which is considered to be associated with the convection of the vortical structure in the near-wall region. As a result, it was confirmed that the maximum position of the time-averaged heat transfer was not coincide with the time-averaged flow reattachment position, as it has been reported in the literature. In order to investigate the mechanism of this, ensemble-averaged heat transfer coefficients were calculated on the condition that instantaneous reattachment appeared at specific streamwise positions. The ensemble-averaged heat transfer coefficient shows a noticeable peak at the flow reattachment position. Also, the peak value of the ensemble-averaged heat transfer coefficient tended to decrease toward downstream. This trend indicates that the flow reattachment at upstream contributes to the heat transfer enhancement more significant than that at downstream. This is the reason why the maximum position of the time-averaged heat transfer exists upstream of the time-averaged flow reattachment position.
\end{abstract}

Key words : Heat transfer, Forced convection, Separation, Reattachment, Unsteady flow

\section{1. 緒言}

熱流体機器の多くは，はく離・再付着流れを伴い，しばしばその性能に影響を及ぼす。はく離流れが再付着す る領域では伝熱が促進されるため，これは時に局所の熱伝達変動振幅を増大させ，壁面材料の熱疲労の原因にな る(日本機械学会, 2003). 一方, はく離・再付着流れに伴う伝熱促進を応用し, 各種機器の高性能化も試みられて きた(望月，2000). この伝熱促進現象は，壁面近傍の乱流渦構造の挙動と密接に関連していると考えられており， 従来, 流れの再付着領域における速度場・温度場に関する研究が多数行われてきた.例えば, Krall and Sparrow (Krall and Sparrow, 1966)は，円管内オリフィス下流において，オリフィス開口比，レイノルズ数を系統的に変更し，熱 伝達率の流れ方向分布を測定した. その結果, オリフィス下流における熱伝達率は, はく離点から円管直径の 1.25 ～ 2.5 倍下流において極大をとり，その值は十分発達した領域における熱伝達率の $3 \sim 9$ 倍高くなることを明らか にした．中丸ら(中丸他, 1980)は，感温液晶法を用い，後向きステップ後方の再付着領域における壁温変動を観測 した，その結果，スパン方向にはステップ高さと同程度の非一様構造が形成されることを示した。また，熱伝達 率の極大位置が流れの再付着位置よりも上流側に存在することを確認した．鈴木ら(鈴木他, 1982)は，円管内オリ フィス下流において熱伝達率分布を測定するとともに，油膜法により壁面近傍の流れ場を可視化し，時間平均的

No.16-00067 [DOI:10.1299/transjsme.16-00067], J-STAGE Advance Publication date : 19 July, 2016

*1 正員, 防衛大学校 理工学研究科後期課程 装備・基盤工学系専攻（干239-8686 神奈川県横須賀市走水 1-10-20)

*2 正員, 防衛大学校 システム工学群 機械工学科

E-mail of corresponding author: nhajime@nda.ac.jp 
な温度場と流れ場の対応関係を考察した，その結果，熱伝達率の極大位置が流れの再付着位置よりも上流側に存 在することを示した. Vogel and Eaton (Vogel and Eaton, 1985)は, 加熱金属䇴を後向きステップ再付着領域に設置し て熱伝達測定を行った．また，レーザードップラー流速計により壁面近傍の速度変動を測定した，その結果，速 度変動が大きい領域ほど伝熱が促進されることを示した。ささらに，サーマルタフトプローブにより流れの再付着 位置を評価し, 熱伝達率の極大位置が流れの再付着位置よりも上流側に存在することを示した.

このように, 従来から熱伝達率の極大位置は流れの再付着位置よりも上流側に存在することが示されてきた(中 丸他, 1980) (鈴木他, 1982) (Vogel and Eaton, 1985). このメカニズム解明のため, 森ら(森他, 1986)は, 後向きステッ プ再付着領域において，サーマルタフトプローブを用いた瞬時再付着位置の測定と熱流束センサを用いた熱伝達 の非定常測定を行った. 測定結果に基づき, 時空間的に普遍的な瞬時熱伝達率分布の存在を仮定することにより, 上記位置の違いを説明した．河村ら(河村他, 1988)は，後向きステップ再付着領域に熱流束センサを配列して，瞬 時熱伝達率分布の時系列データを収集した。 また, 瞬時熱伝達率の極大位置を瞬時再付着位置とみなした統計解 析を行い, 上記位置の違いを考察した. 森ら(森他, 1986)の手法は, 流れの再付着位置における流動と伝熱の対応 に関する一つのモデルを提示するものであるが, 瞬時熱伝達率分布が測定されておらず, 普遍的な瞬時熱伝達率 分布の存在が検証されていない, 一方, 河村ら(河村他, 1988)の手法は, 従来の時間平均的な議論を脱し, 流れ場 と温度場の非定常測定からアプローチ寸るものであり, 問題の本質に迫るものであった. しかし, 再付着判定位 置と熱伝達測定位置がスパン方向にずれており, さらに現象の複雑さに対して測定点も十分とは言えない.すな わち, 従来の研究では, 時間平均再付着位置と時間平均熱伝達率極大位置が異なる原因について十分に明らかに されているとは言えない.

著者らは，これまで高速度赤外線カメラを用いた手法により円管内の十分発達した領域における乱流熱伝達を 測定してきた(椎原他, 2013)．その結果, 熱伝達率の瞬時分布及びその変動が定量的に測定可能であることを確認 した．続いて, 赤外線カメラを用いた手法を, 円管内オリフィス周囲のはく離・再付着を伴う流れ場に適用し, 熱伝達の瞬時分布及びその非定常挙動を測定した(Shiibara et al., 2015). その結果，オリフィス下流では，十分発 達した領域に比べて熱伝達率が非常に激しく変動するとともに, 熱伝達構造が非常に細かくなることを明らかに した. 本報では, 円管内オリフィス周囲における時々刻々と変化する熱伝達構造を基に, 瞬時再付着位置と瞬時 熱伝達率極大位置の評価を試みた。ささらに, 瞬時・局所における熱伝達構造の移動速度および熱伝達率を統計的 に解析した. その結果に基づき, 河村ら(河村他, 1988)の手法を参考に, 時間平均再付着位置と時間平均熱伝達率 極大位置が異なる原因について考察する.

\section{主な記号}

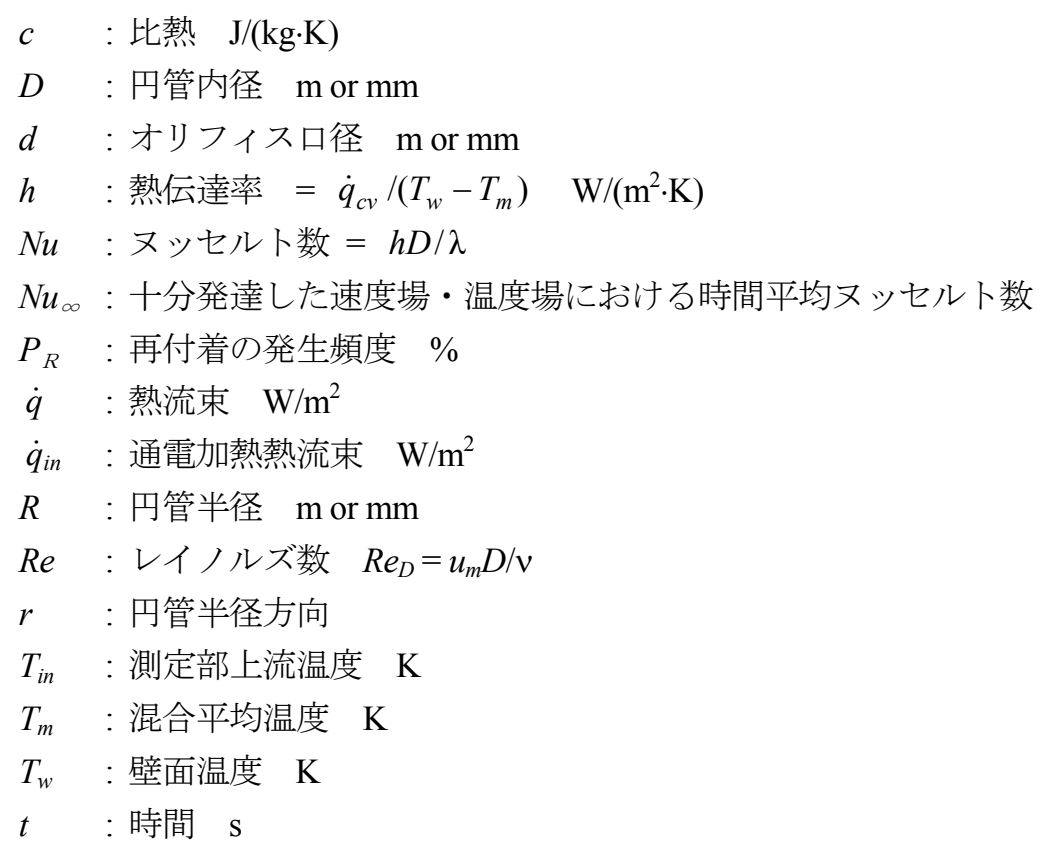




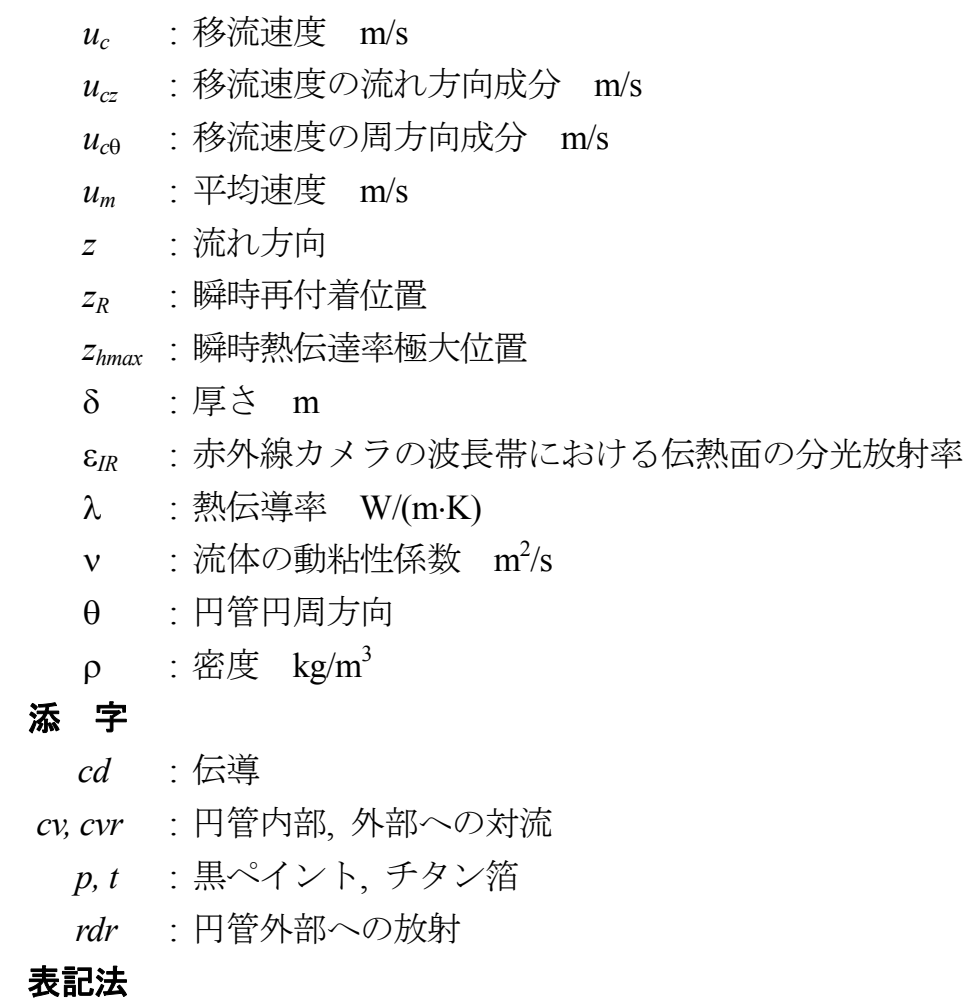

(') : 平均值

\section{2. 実験装置及び方法}

図 1(a)に実験装置の全体図を示す。装置は，(1)ヘッドタンク，(2)整流水槽，(3)円管助走部，(4)測定部，(5)出 口部, (6)出口水槽から構成されている. 整流水槽にはヘッダーが設置されており, 円管出口とヘッド差 $(1150 \mathrm{~mm})$ をつけることで水流を発生させた．図 1(b)に整流水槽を示寸．整流水槽には温度プローブを扦入し，測定部上流 側水温 $T_{i n}$ を計測した. 円管助走部の上流端には円管入口の乱れを抑制するためにベルマウスを設置した. 整流 水槽の出口（円管流路入口）には，遷移領域において安定して乱流を持続させるために乱流促進体（直径 $1 \mathrm{~mm}$ のワイヤをリング状にしたもの）を設置した．円管の内径は $D=20.4 \mathrm{~mm}$ ，助走部の長さは $L=1040 \mathrm{~mm}$ である $(L / D=51)$ ．測定部にはアクリル製のオリフィス板を設置した（図 $1(\mathrm{c})$ ). オリフィス板は，厚さ $2 \mathrm{~mm}$, 絞り 口径 $d=10 \mathrm{~mm}$ (開口比 $d / D=0.49$ ), であり, 下流側エッジには 45 度の逃げ角を設けた. 円管内の平均流速は, 出口水槽へ流出した流量を計量カップで測定して求めた. 平均流速は $u_{m} \approx 0.5 \mathrm{~m} / \mathrm{s}$ であり, 対応するレイノルズ数 は $R e_{D} \approx 13000$ である. なお，赤外線カメラによる測定では，測定面温度 $T_{w}$ と周囲壁面温度の差が大きいほど 感度が向上するため, 出口水槽内にサーモスタット付きのヒーターを設置し, ポンプで水を循環させることで装 置内の水温を $30^{\circ} \mathrm{C}$ 程度まで高めた.

図 2 に，熱伝達測定用の伝熱模型を示す．図2(a),(b) に，それぞれ模型の写真および断面構造（水平断面図） を示す. アクリル円管（長さ $280 \mathrm{~mm}$ ）の中央部断面を，長さ $240 \mathrm{~mm}$ にわたって半円状に切り取り，円管の内面 に沿ってチタン箔（厚さ $\delta_{t}=20.7 \mu \mathrm{m} ）$ を接着した．円管の両端には電極を設置し，これを介してチタン管を通 電加熱した. 伝熱面の放射率を高めるため, チタン管の外面には黒ペイントを塗布した（塗布厚さ $\delta_{p} \approx 20 \mu \mathrm{m}$ ). 伝熱面（チタン䈃十黒ペイント）は熱容量が非常に小さく, 管内水流への熱伝達変動に伴って壁温が高速に変動 する. この壁温変動を高速度赤外線カメラ（SC4000, FLIR，以下 IRT と記す）で測定した．また，外部からの放 射の影響を抑制するとともに，周囲壁面温度を均一にするため，図 2(c) のように，内側に黒ペイントを塗布した 銅板で測定部を覆った，オリフィス板は，加熱開始点から $80 \mathrm{~mm}$ 下流に上流端が位置するように設置し，流れ方 向 $z$ の起点は流れのはく離点（オリフィス板上流端中央, 図 2(b) 参照) とした. なお, 測定は, オリフィス上 流側から $z / D=-2.4 \sim 0.3,0.7 \sim 4,5.6 \sim 8.9$ の 3 領域に分けて行った. 装置および実験方法の詳細は文献(椎原他, 2013) (Shiibara et al., 2015)を参照されたい. 


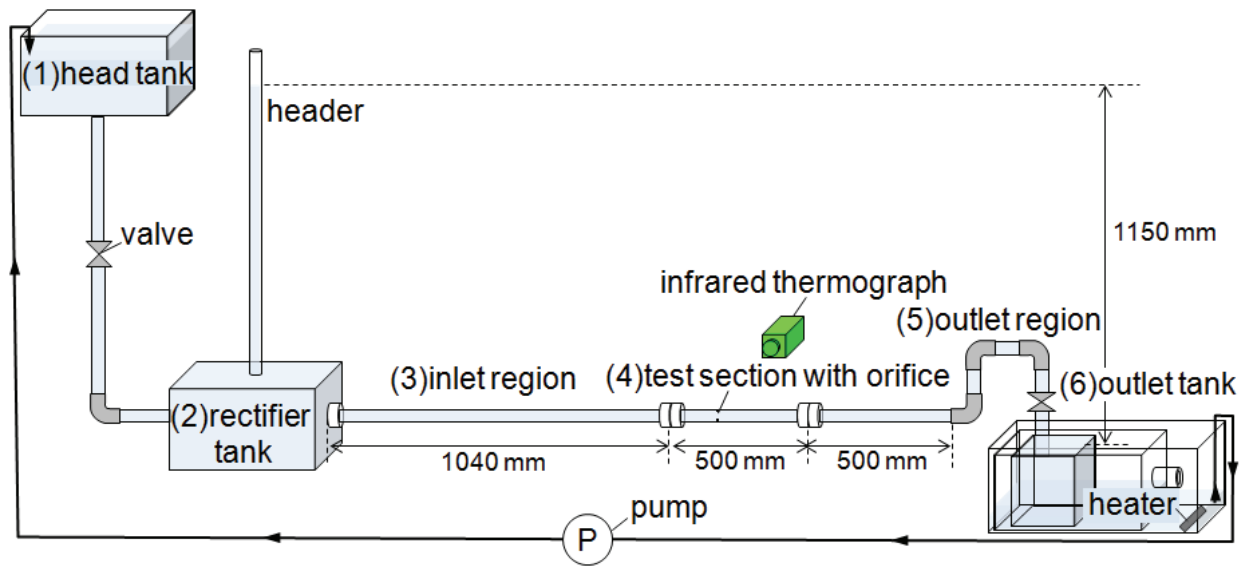

(a) Entire setup

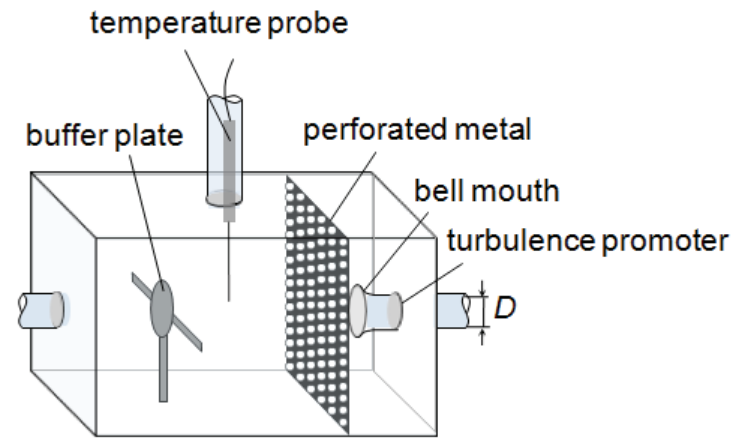

(b) Rectifier tank

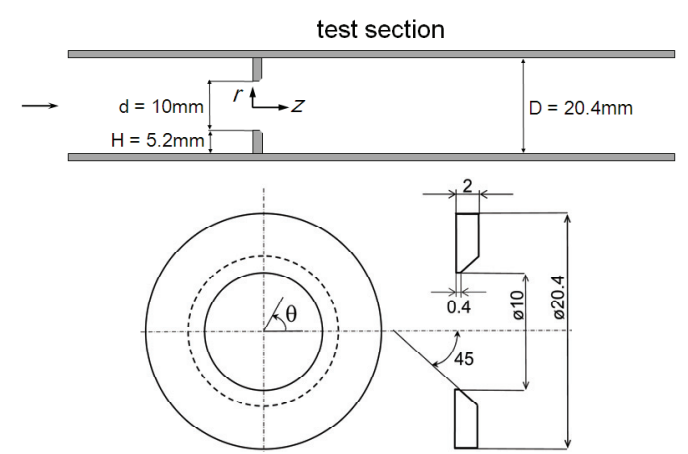

(c) Orifice plate

Fig.1 Experimental setup. Water flow was generated by hydraulic head and was circulated by a water pump.

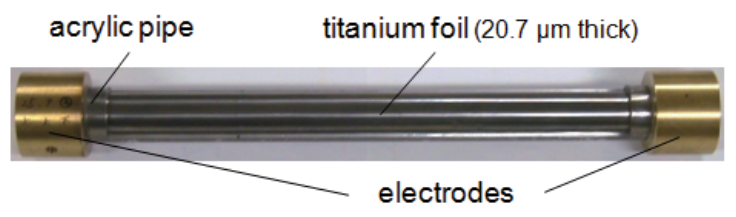

(a) Photograph

(before coating with black paint)
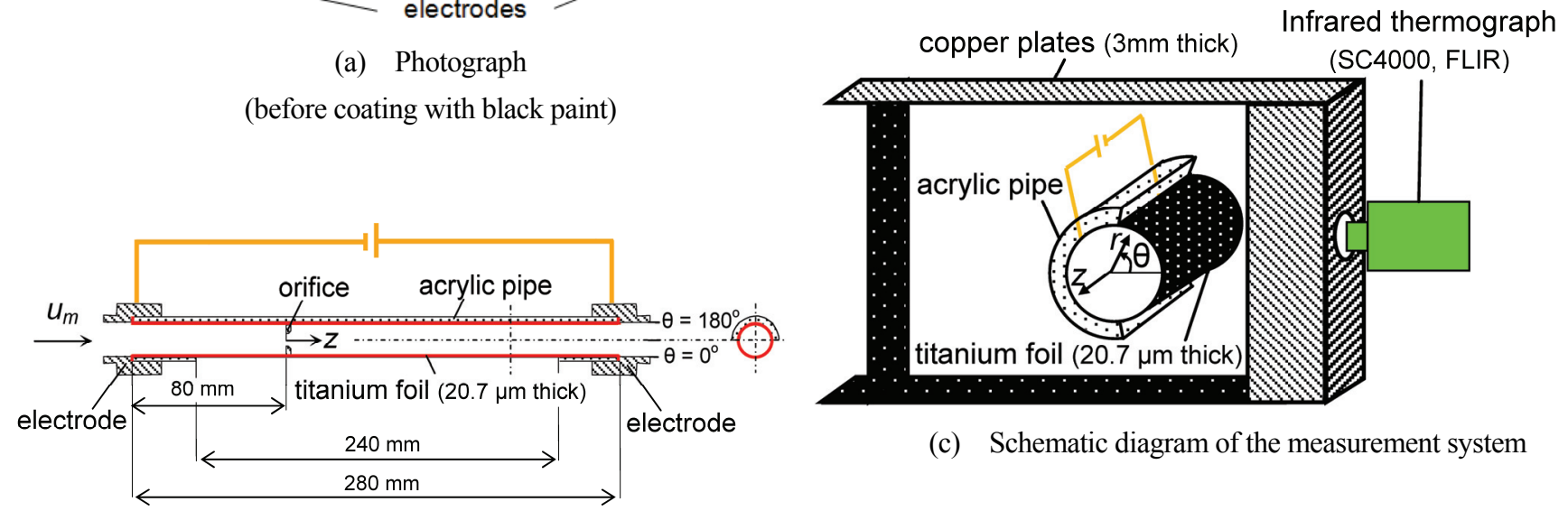

(c) Schematic diagram of the measurement system

(b) Top cross-sectional view (with an orifice)

Fig. 2 Test section for heat transfer measurement. Test surface was composed of thin titanium foil coated with black paint and was heated electrically. The instantaneous temperature distribution and its temporal fluctuation on the test surface were measured using a high-speed infrared thermograph (SC4000, FLIR). 


\section{3. 実験結果及び考察}

\section{$3 \cdot 1$ 伝熱面の瞬時温度分布}

図 3 に，IRT で測定されたオリフィス周囲における熱画像の一例を示す。画像の濃い色が低温部を，薄い色が 高温部を表している. 図3(a), (b), (c) はそれぞれ，オリフィス上流，流れのはく離再付着領域および回復領域の 熱画像である. ここで，周方向は円管の曲面を平面に投影したものとなっている．伝熱面の放射率は， $|\theta|<45^{\circ}$ 程度までであれば一定とみなすことができ，この範囲では伝熱面温度 $T_{w}$ は垂直放射率を用いてほぼ正しく測定 できる.なお，いずれの領域においても，時間平均的には周方向の温度差は小さく，浮力の影響は小さいことを 確認した.
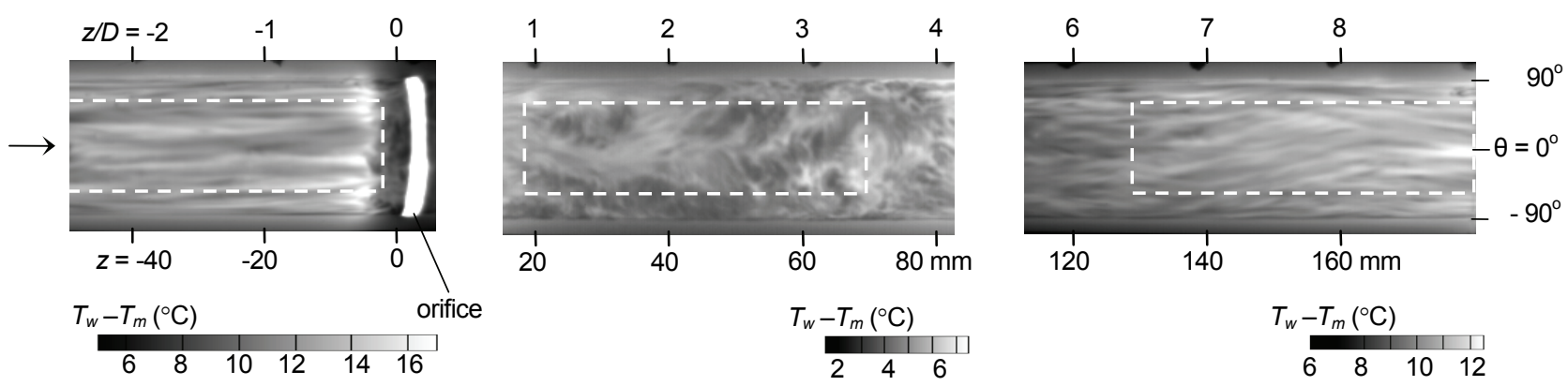

(a) $z / D=-2.4$ to $0.3(z=-49$ to $6 \mathrm{~mm})$

(b) $z / D=0.7$ to $4(z=14$ to $81 \mathrm{~mm})$

(c) $z / D=5.6$ to $8.9(z=114$ to $182 \mathrm{~mm})$

Fig. 3 Instantaneous thermal-image of the heated surface measured using IRT: (a) just upstream of the orifice; (b) around flow reattachment region; (c) flow recovering region. $z$ is streamwise distance from upstream edge of the orifice.

\section{$3 \cdot 2$ 熱伝達率の算出}

困 4 に，伝熱面断面の熱移動の模式図を示す。伝熱面（チタン箔十ペイント）の温度が厚さ方向に一様と仮定 すると，伝熱面内の熱伝導方程式は次式で表される.

$$
\left(c_{t} \rho_{t} \delta_{t}+c_{p} \rho_{p} \delta_{p}\right) \frac{\partial T_{w}}{\partial t}=\lambda_{e}\left(\delta_{t}+\delta_{p}\right)\left(\frac{\partial^{2} T_{w}}{\partial z^{2}}+\frac{1}{R^{2}} \frac{\partial^{2} T_{w}}{\partial \theta^{2}}\right)+\dot{q}_{i n}-\dot{q}_{c v}-\dot{q}_{c v r}-\dot{q}_{r d r}
$$

ここで， $T_{w}$ はIRT で測定した伝熱面の瞬時・局所の温度である． $c, \rho, \delta ， \lambda$ はそれぞれ比熱，密度，厚さ，熱 伝導率，添え字の $t, p$ はそれぞれチタン筞，ペイントを表している. $\lambda_{e}=\left(\lambda_{t} \delta_{t}+\lambda_{p} \delta_{p}\right) /\left(\delta_{t}+\delta_{p}\right)$ は伝熱面の面方向 の実効的な熱伝導率である. $\dot{q}_{i n}$ は通電加熱熱流束, $\dot{q}_{c v}$ は水流への対流熱流束であり, 次式で表される.

$$
\dot{q}_{c v}=h\left(T_{w}-T_{m}\right)
$$

ここで， $T_{m}$ は局所における混合平均温度であり，測定部の上流温度 $T_{i n}$ をもとに，水流への対流熱流束による温 度上昇を考慮して算出した(Shiibara et al., 2015). 局所混合平均温度 $T_{m}$ にて定義される熱伝達率の使用が，循環流 を伴うオリフィス下流に対して最適か否かは不明であるが，本実験結果を従来の研究(Krall and Sparrow, 1966) (鈴

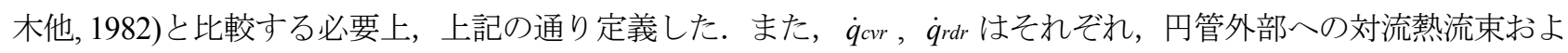
び放射熱流束を示している． $\dot{q}_{c v r}$ は水平円管周りの自然対流の経験式(Fujii, et al., 1982)から見積もり， $\dot{q}_{r d r}$ は伝熱 面を灰色面と仮定した場合の放射エネルギーから見積もった（赤外線カメラの波長帯における伝熱面の分光放射 率 $\varepsilon_{I R}=0.96$ を全放射率と仮定した). なお, 円管外部への対流熱流束 $\dot{q}_{c r r}$ と放射熱流束 $\dot{q}_{r d r}$ を合わせても，通電 加熱熱流束 $\dot{q}_{i n}$ の $0.5 \%$ 以下と小さかった.

円管内水流への瞬時・局所の熱伝達率 $h$ は, 式(1), (2)から導出される次式から算出した. なお, 本研究では, 図 3 の破線で囲まれた領域の熱伝達率を算出した. 


$$
h=\frac{\dot{q}_{i n}-\dot{q}_{c v r}-\dot{q}_{r d r}+\lambda_{e}\left(\delta_{t}+\delta_{p}\right)\left(\frac{\partial^{2} T_{w}}{\partial z^{2}}+\frac{\partial^{2} T_{w}}{\partial(R \theta)^{2}}\right)-\left(c_{t} \rho_{t} \delta_{t}+c_{p} \rho_{p} \delta_{p}\right) \frac{\partial T_{w}}{\partial t}}{T_{w}-T_{m}}
$$

ここで, $\lambda_{e}\left(\delta_{t}+\delta_{p}\right)\left(\partial^{2} T_{w} / \partial z^{2}+\partial^{2} T_{w} / \partial(R \theta)^{2}\right)$ は管の温度分布による面方向の熱伝導を, $\left(c_{t} \rho_{t} \delta_{t}+c_{p} \rho_{p} \delta_{p}\right) \partial T_{w} / \partial t$ は于 タン䇴の熱容量による時間遅れを表しており, これらの項を計算することで, 䇴の温度変動の時空間的な減衰を 復元することができる. 微分項は, 時間刻みを $\Delta t=1.25 \mathrm{~ms}$ (IRT のフレーム間隔), 空間刻みを $\Delta z \approx \Delta(R \theta) \approx 0.21$ $\mathrm{mm}$ (IRT のピクセル間隔) として差分法により計算した. なお, 差分解析には時空間的な減衰が伴うため, 文献 (Nakamura and Yamada, 2013)を基に，微分項計算時の時空間的な減衰を評価した．その結果，本実験条件 $\left(R e_{D} \approx\right.$ 13000) では, 減衰が最も大きくなるオリフィス下流側の再付着領域（代表的な空間構造 $3 \mathrm{~mm}$ 程度, 代表的な変 動周波数 $10 \sim 50 \mathrm{~Hz}$ 程度) においても, 時間・空間いずれの変動振幅の減衰も 5 \%程度以下と小さかった. また, 熱伝達変動が高速になると伝熱面厚さ方向の温度分布が無視できなくなり, 熱伝達率の変動振幅が十分復元でき なくなる，そこで，本実験で用いた伝熱面について IRT の実測データを基に一次元熱伝導解析を行って検討した ところ, オリフィス下流側の再付着領域 (代表的な変動周波数 $10 \sim 50 \mathrm{~Hz}$ 程度) においても変動振幅の減衰は $10 \%$ 以下であり，熱伝達構造の代表的な変動パターンは復元可能であることを確認した.

算出された熱伝達率の不確かさを確かめるために, アメリカ機械学会性能試験規約(日本機械学会, 1987)に基づ き, 本研究における代表的な条件 (オリフィス上流 $z / D=-1(z=-20 \mathrm{~mm})$ および再付着位置 $z / D=2(z=40 \mathrm{~mm})$ ) の誤差評価を行った. 式(3)中の熱流束 $q_{i n}-q_{c v r}-q_{r d r}$, 熱拡散項 $\lambda_{e}\left(\delta_{t}+\delta_{p}\right)\left(\partial^{2} T_{w} / \partial z^{2}+\partial^{2} T_{w} / \partial(R \theta)^{2}\right)$, 熱慣性項 $\left(c_{t} \rho_{t} \delta_{t}+c_{p} \rho_{p} \delta_{p}\right) \partial T_{w} / \partial t$ および温度差 $T_{w}-T_{m}$ について, それぞれ誤差要因を列挙し, 評価した. その結果, 才 リフィス上流 $z / D=-1 \quad(z=-20 \mathrm{~mm})$ では, 熱伝達率の瞬時・局所值の相対誤差（95\%包括度）は $4.5 \%$, 時空間 平均值の相対誤差 $(95 \%$ 包括度) は $3.6 \%$ と評価された. 再付着位置 $z / D=2(z=40 \mathrm{~mm})$ では, 熱伝達率の瞬時・ 局所值の相対誤差（95\%包括度）は $6.6 \%$ ，時空間平均值の相対誤差（95\%包括度）は $5.6 \%$ と評価された.

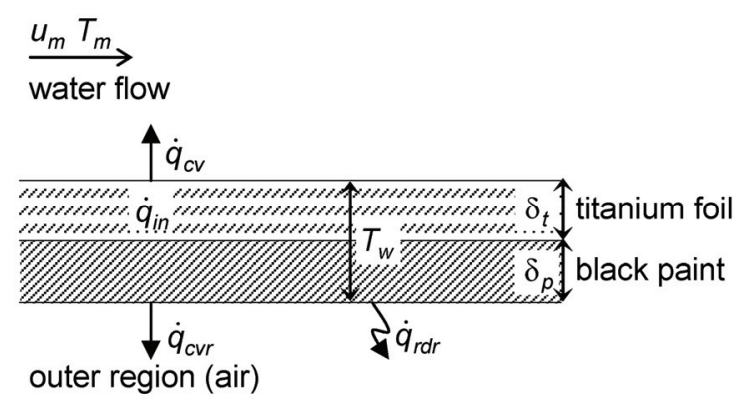

Fig. 4 Schematic diagram of the heat transfer from a heated surface, which is composed of thin titanium foil coated with black paint. $\dot{q}_{i n}$ is the input heat flux to the thin foil due to Joule heating. $\dot{q}_{c v}$ is the convective heat flux to the water flow. $\dot{q}_{c v r}$ and $\dot{q}_{r d r}$ are the heat fluxes to the outside due to convection and radiation, respectively.

\section{$3 \cdot 3$ 熱伝達率の瞬時分布}

図 5 に，図 3 と同時刻における熱伝達率の瞬時分布の一例を示す。ここで，図 5 の熱伝達率分布は IRT で測定 した伝熱面の投影断面を $z-\theta$ 面に座標変換し表示している. オリフィス上流（図 5 (a)）では，流れ方向に伸び た筋状の構造が確認できる.この構造は, 円管内における十分発達した領域における測定(椎原他, 2013)で観測さ れたものと同様であった. オリフィス板の上流端ではく離した流れは, 開口比 $d / D=0.5$ の場合は下流側 $z / D \approx 2.2$ ～ 2.6 の位置に再付着寸ることが知られている(鈴木他, 1982) (Deotte et al., 1991) (木綿他, 2013). 図 5 (b)を見ると, この領域の周囲ではオリフィス上流に見られた筋状の構造は見られなくなり, スポット的な細かな熱伝達構造を 呈している. また, オリフィス板上流（図 5(a)）に比べ, 熱伝達率の值が数倍高くなっていることがわかる. こ 


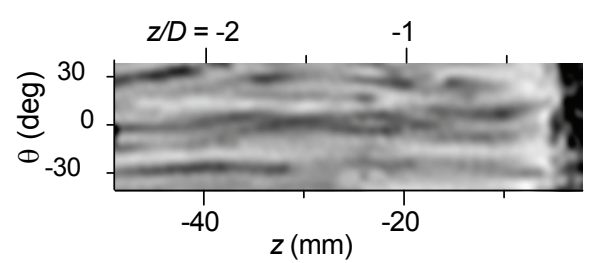

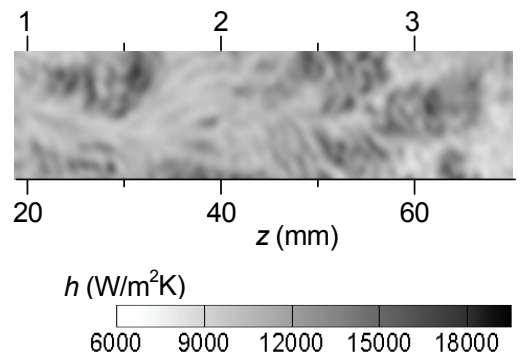

(b) $z / D=0.9$ to 3.4

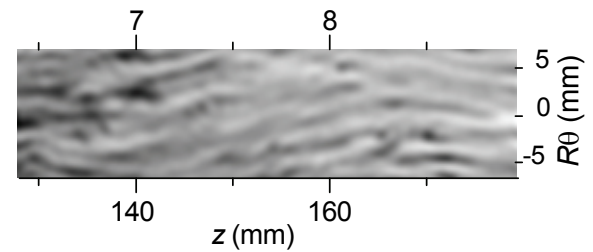

$h\left(\mathrm{~W} / \mathrm{m}^{2} \mathrm{~K}\right)$

$3000 \quad 4000 \quad 5000 \quad 6000 \quad 7000$

(c) $z / D=6.3$ to 8.9

Fig. 5 Instantaneous distribution of heat transfer coefficient calculated using Eq. (3). The calculated regions are corresponding to the dotted lines of Fig.3.

の伝熱促進は，オリフィス板での縮流による流れの加速，および流れの再付着による低温流体の壁面近傍への流 れ込みによるものと考えられる. 図 5(c)の回復領域では, 再び筋状の構造が現れる. ただし，構造はオリフィス 上流（図 5(a)）に比べると大きく蛇行しており, 熱伝達率がオリフィス上流よりもやや高いことから, この位置 $(z / D=6.3 \sim 8.9)$ ではオリフィス板による乱れの影響が残っており，流れが完全には回復していないことがわか る.

図 6 に, 時間平均したヌッセルト数 $\overline{N u}=\bar{h} D / \lambda$ の流れ方向分布を示寸. なお, 水の熱伝導率 $\lambda$ は, 従来の研 究(Krall and Sparrow, 1966) (鈴木他, 1982)の定義と同様, 測定部上流温度 $T_{\text {in }}$ におる值を使用した. 赤色のプロッ トが本実験結果である.縦軸は従来の経験式(Gnielinski, 1976)から見積もった, 円管内の十分発達した速度場・温 度場における時間平均ヌッセルト数 $N u_{\infty}$ で規格化している. なお, 前報(椎原他, 2013)において, $R e_{D}>5000$ では, 円管内の時間平均ヌッセルト数が従来の経験式(Gnielinski, 1976)と $5 \%$ 以内で一致することを確認している. 本実 験ではオリフィス下流 $z / D=2.2$ において極大值をとっている. 本実験の妥当性を確認するために, 従来の実験 結果（オリフィス板の開口比 $d / D=0.5 ）$ を破線(Krall and Sparrow, 1966)及び点線(鈴木他, 1982)で示した. プラン トル数, 熱的境界条件および加熱開始点などの条件に違いがあるものの, 極大位置及びその前後の分布の傾向は 概小一致しており, 定量的に妥当な值が測定できていると考えられる.

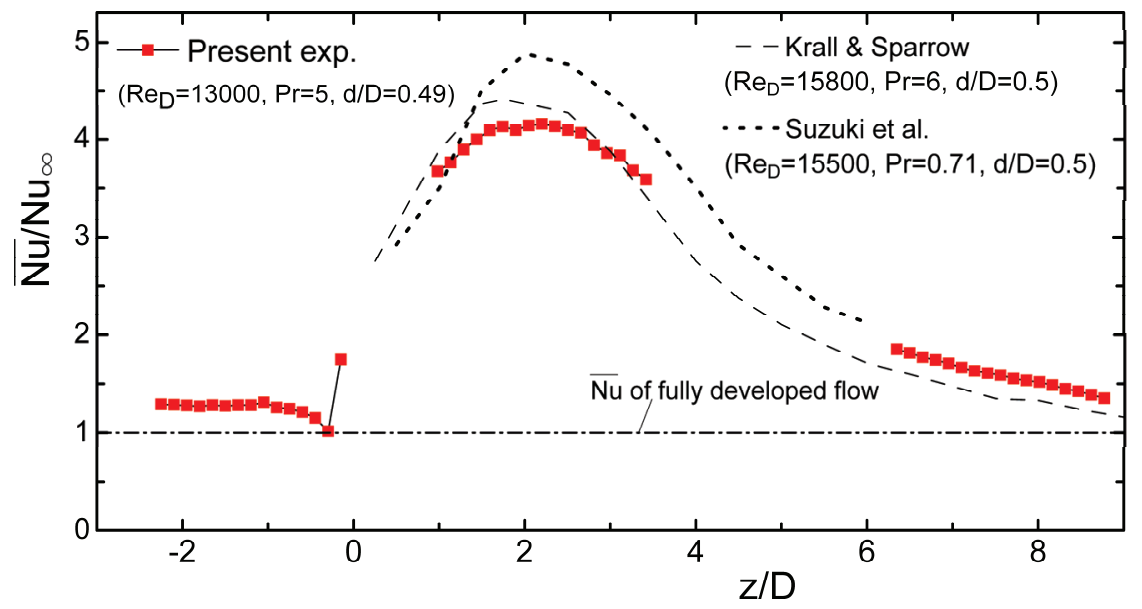

Fig. 6 Time-averaged Nusselt number distribution. Nusselt number of the present experiment has a maximum at $z / D=2.2$.

The value and the trend of the present experiment corresponds fairly well to that of the previous experiments.

\section{$3 \cdot 4$ 熱伝達構造の移流速度評価}

次に, 時々刻々と変化する熱伝達構造の移動速度を評価した，この熱伝達構造の移動は壁面近傍における渦構 造の移動に対応するものと考えられる.ここでは熱伝達構造の移動速度を移流速度と呼ぶこととする. なお, PIV 
と赤外線カメラを用いて後向きステップ下流の再付着位置における速度変動と熱伝達変動を同時計測した結果 (Yamada and Nakamura, 2015), 壁面近傍における流れ方向・壁面垂直方向の速度変動と熱伝達変動の間には強い相 関が現れることが示されている，作動流体や流路形状に違いがあるものの，本研究においても，熱伝達変動から 評価した移流速度は，壁面近傍における速度変動と密接に関係していると考えられる.

移流速度は，瞬時熱伝達率分布の時系列画像を汎用 PIV 解析ソフトウェア (Flow Expert 2D, カトウ光研（株) ) を用いて解析することにより評価した。瞬時熱伝達率分布のピクセル間隔は $0.21 \mathrm{~mm}$ 程度（= IRT のピクセル間 隔), 画像間の時間差は $1.25 \mathrm{~ms}$ (= IRT のフレーム間隔) である. 検查領域サイズは $24 \times 24$ pixel とし，隣接する 検查領域と 50 \%オーバーラップするよう設定した. この時, 検查領域の辺長は $D / 4$ 程度であり, 流れ方向 17 点 $\times$ 周方向 2 点で解析を行った. 解析された移流速度 $u_{c}$ の流れ方向成分を $u_{c z}$, 周方向成分を $u_{c \theta}$ と表記する. な お, 解析された速度ベクトルのうち, 移流速度の大きさ $\sqrt{u_{c z}{ }^{2}+u_{c \theta}{ }^{2}}$ が閾值 (オリフィス上流側では平均流速 $u_{m}$ の 2 倍, オリフィス下流側では $u_{m}$ の 4 倍 $\approx$ オリフィス開口部における流速）を超えるベクトルを過誤ベクトル と判断し，後処理において除去した．除去された過誤ベクトルの数は全ベクトルの $0.01 \%$ 末満であった.

図 7 に, オリフィス下流側における熱伝達率のコマ送り及び算出された移流速度ベクトルの一例を示す．速度 ベクトルを見ると, この瞬間はオリフィス下流 $z / D=2.7$ 付近まで逆流が支配的であり, その後逆流から順流へ移 行している様子が分かる.

ここで得られた移流速度ベクトルの妥当性を検証するため, まず, 図 7(b)の移流速度ベクトルを全時間 (計 8173 フレーム）にわたって平均したものを図 8 に示寸. また, 3 つの領域 $(z / D=-2.4 \sim-0.1,0.9 \sim 3.4,6.3 \sim 8.9)$ で 求めた移流速度の時間平均值 $\overline{u_{c z}} / u_{m}$ を図 9 に示す. 図 8 より, 移流速度を時間平均すると, 周方向に一様かつ周 方向成分がほぼ 0 となっており, 定性的に妥当な分布となっている. また図 9 より, 移流速度は流れ場と対応し た妥当な分布傾向を示している. 寸なわち, オリフィス上流側では移流速度が $0.4 u_{m}$ 程度でほぼ一定であるが, オリフィス直前 $(z / D>-0.5)$ では流れが堰き止められて急低下する. 循環流を伴うオリフィス下流側はく離領域 では逆流となり, 移流速度が負の值を示寸. その後, $z / D=2.7$ 付近を過ぎると順流へと移行し, 流れの回復領域
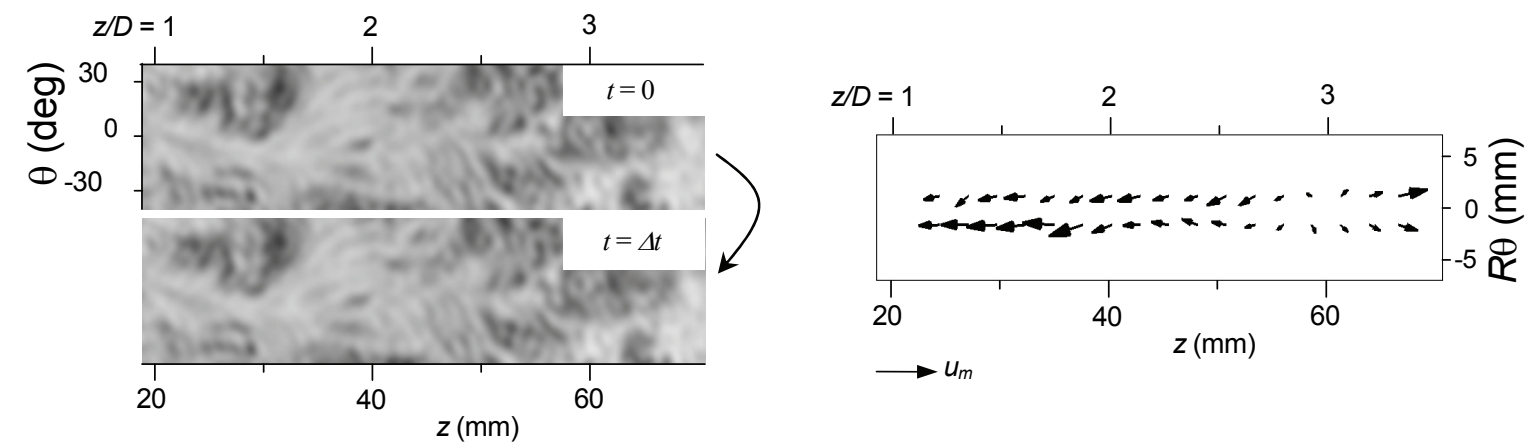

(a) Frame-by-frame images of instantaneous heat transfer coefficient (b) Instantaneous convection velocity vectors

Fig. 7 An example of the instantaneous convection velocity vectors calculated using PIV software in the region of $z / D=1.1$ to 3.3 (time interval $\Delta t=1.25 \mathrm{~ms}$ ).

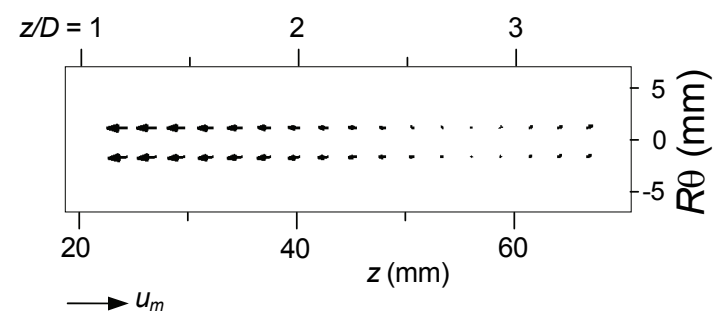

Fig. 8 Time-averaged vectors of the convection velocity in the region of $z / D=1.1$ to 3.3 . Circumferential component becomes almost zero after time-averaging. This indicates that the instantaneous vectors calculated here seems to be reasonable. 
$(z / D=6.4 \sim 8.5)$ では，オリフィス上流側の移流速度と同程度になっている.

次に，PIV 解析ソフトウェアを用いて評価した移流速度が定量的に妥当であるか検証するため，流れ方向 $(z)-$ 時間 $(t) の 2$ 次元自己相関(Shiibara et al., 2013)からも移流速度を評価した. 2 次元自己相関は, 瞬時熱伝達率分布 $(z$ 範囲 $8 \mathrm{~mm})$ の時系列データから次式を用いて計算した.

$$
R_{h}(\Delta z, \Delta t)=\frac{\overline{h(z, t) \cdot h(z+\Delta z, t+\Delta t)}}{\sqrt{\overline{h_{(z, t)^{2}}} \cdot \overline{h(z+\Delta z, t+\Delta t)^{2}}}}
$$

$\mathrm{PIV}$ 解析と同様に, $\Delta t=1.25 \mathrm{~ms}$ (=IRT のフレーム間隔) として移流速度を評価し, 図 9 に印でプロットした。 PIV 解析ソフトウェアにより評価した值は 2 次元自己相関から評価した值とよく一致しており，定量的に妥当な 移流速度が評価できていることを確認した。

従来の研究(鈴木他, 1982) (Deotte et al., 1991) (木綿他, 2013)では, 開口比 $d / D=0.5$ の場合, オリフィス下流 $z / D$ $\approx 2.2 \sim 2.6$ の位置に流れが再付着することが示されているが, $\overline{u_{c z}} / u_{m}=0$ となる位置を流れの再付着位置と定義す れば，図 9 より，本実験の再付着位置は $z / D=2.7$ と評価できる.また，鈴木ら(鈴木他，1982)は，Re $e_{D}=15500 に$ おいて熱伝達率の極大位置は流れの再付着位置よりも $0.3 D$ 程度上流側に存在することを示しているが, 本研究で は，熱伝達率の極大位置 $(z / D=2.2)$ は流れの再付着位置 $(z / D=2.7)$ よりも $0.5 D$ 程度上流側であった。

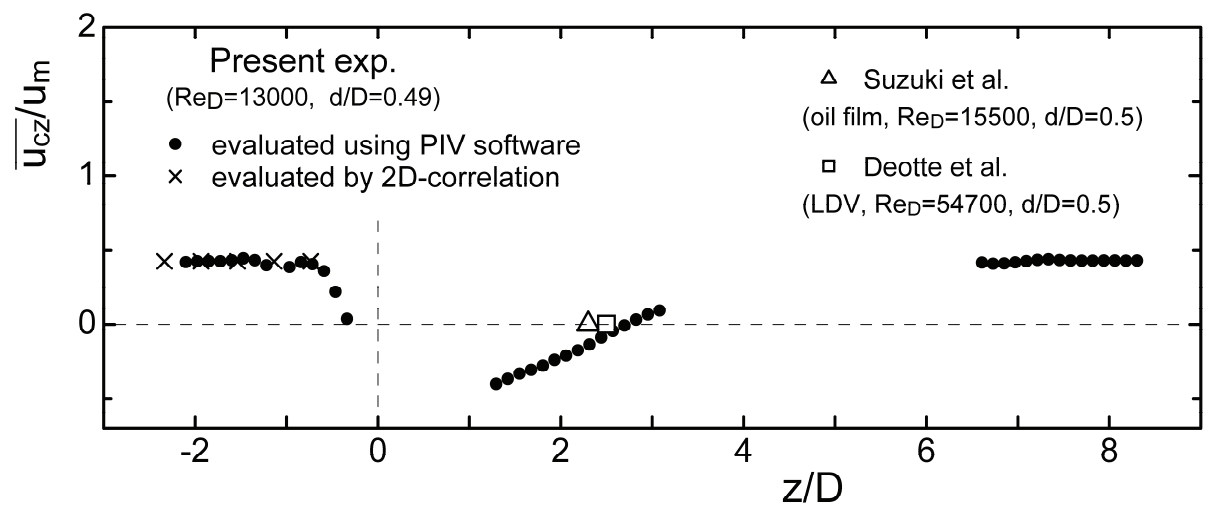

Fig. 9 Distribution of time-averaged streamwise convection velocity $\overline{u_{c z}} / u_{m}$, which was evaluated using PIV software. The trend of the convection velocity evaluated by PIV reasonably corresponds to that of the flow field. That is, the convection velocity keeps constant value (about $0.4 u_{m}$ ) at upstream of an orifice, and it immediately decreases at $z / D>$ -0.5 due to damming effect by the orifice. In the recirculation region at downstream of the orifice, the convection velocity shows negative value reflected by the backward flow. Then it changes to positive value at $z / D>2.7$. In the recovery region $(z / D=6.4 \sim 8.5)$, the convection velocity becomes almost the same as that upstream of the orifice. The value of the convection velocity evaluated by PIV at upstream of the orifice agreed well with that evaluated by streamwise-time autocorrelation (shown by “ $\times$ ”) defined as Eq.(4). The reattachment position of the present study defined by $\overline{u_{c z}} / u_{m}=0$ was $z / D=2.7$, which fairly agreed to that of the previous studies.

\section{$3 \cdot 5$ 再付着位置と熱伝達極大位置の相違の考察}

前述のように, 時間平均的な再付着位置 (以後 $\overline{z_{R}}$ と記す) と時間平均的な熱伝達率極大位置 (以後 $\overline{z_{h \max }}$ と 記す) が一致しないことが従来から指摘されてきた(中丸他，1980) (鈴木他，1982) (Vogel and Eaton 1985) (森他, 1986) (河村他, 1988). 本研究では, 河村ら(河村他, 1988)の手法を参考に, 瞬時再付着位置 $z_{R}$ と瞬時熱伝達率極大 位置 $z_{\text {hmax }}$ の対応から，上記位置の違いについて考察する.

図 10(a)の上段に，PIV 解析ソフトウェアにより評価した瞬時移流速度分布 $(R \theta=1.3 \mathrm{~mm})$ の一例を示す．図中の ○は, 図 7(b)のベクトルと対応している.この瞬間, 移流速度はオリフィス下流 $z / D=2.7$ 付近まで負の值であり, その後正の值へと移行している. つまり, はく離した流れはオリフィス下流 $z / D=2.7 \sim 2.8$ において再付着してい 
ると考えられる. 本研究では, 流れ方向に連続した 4 つの移流速度を 1 組とし, 各点の速度が, 上流から順に負・ 負・正・正の值をとる時に，中央 2 点の間に再付着位置が存在すると判定した，すなわち，この例では $\mathrm{B}, \mathrm{C}$ 間 に再付着位置が存在すると判定される. なお，瞬時移流速度分布にこの条件を満たす点が 2 点以上存在した場合 は，最上流のものを再付着位置とした，図 10(a)下段に，図 10(a)上段と同一位置・同一時刻における瞬時ヌッセ ルト数分布を示寸. この例では, $z / D=2.7 \sim 2.8$ 付近が瞬時ヌッセルト数の極大位置 $z_{\text {hmax }}$ になっており, この瞬間 では，流れの再付着と熱伝達極大が良く対応していることが分かる．また，図 10(b), (c)に，図 10(a)とは異なる時 刻における瞬時移流速度分布（上段）および瞬時ヌッセルト数分布（下段）の例を示寸. 図 10(b)では, $z_{R}$ と $z_{\text {hmax }}$ がずれており, 図 10(c)では, 瞬時ヌッセルト数分布には特徵的なピークが見られない.このように, 必ずしも $z_{\text {hmax }}$ $\approx z_{R}$ になるわけではない. これは, 再付着領域では外部からの低温の流体と壁面近傍で加熱された高温の流体が 3 次元的に複雑に流動するためと推察される. 河村ら(河村他, 1988)の研究では, 瞬時熱伝達率の極大位置を瞬時再 付着位置と仮定して統計解析を行ったが，この仮定は厳密には正しくないと考えられる.

次に, $z_{R}$ と $z_{\text {hmax }}$ の関係を統計的に調べるため, 流れ方向の特定の位置に再付着が現れることを抽出条件として, 瞬時ヌッセルト数分布のアンサンブル平均を求めた. 例えば, 図 10 は特定位置 $z / D=2.70 \sim 2.82$ に再付着が現れ る場合の瞬時ヌッセルト数分布（図 10 下段）を示しているが，この条件を満たす瞬時ヌッセルト数分布を全時系 列データの中から抽出して平均化すると, $z / D=2.70 \sim 2.82$ に再付着が現れるヌッセルト数分布のアンサンブル平 均を求めることができる.ここでは, 14 通りの再付着位置 $(z / D=1.29 \sim 1.42,1.42 \sim 1.55,1.55 \sim 1.68,1.68 \sim 1.80,1.80$ $\sim 1.93,1.93 \sim 2.06,2.06 \sim 2.19,2.19 \sim 2.31,2.31 \sim 2.44,2.44 \sim 2.57,2.57 \sim 2.70,2.70 \sim 2.82,2.82 \sim 2.95,2.95 \sim 3.07)$ を抽 出条件として, 各条件におけるヌッセルト数分布のアンサンブル平均を求めた.

図 11 に, 再付着位置 $z / D \approx 1.5,2,2.5,3$ におけるヌッセルト数分布のアンサンブル平均を示寸. 比較のため, 全時系列データを時間平均したヌッセルト数分布を太い実線で示すが，アンサンブル平均したヌッセルト数分布 は, 抽出条件である再付着位置において顕著に值が上昇していることがわかる. つまり, 瞬時の再付着位置 $z_{R}$ と 瞬時の熱伝達極大 $z_{\text {hmax }}$ は密接に関係しており, 瞬間的には流れが再付着する位置において熱伝達率が高くなる確 率が高いことを示している.また, 再付着位置が上流に位置するほどヌッセルト数の極大值が大きくなっている. すなわち，上流に再付着する流れほど伝熱促進への寄与度が高いことを示している．これは，オリフィス開口部 で増速した流れが下流へ進むほど減速し，下流側では再付着による伝熱促進が弱まるためと考えられる.

図 11 の下段には, 各位置における再付着の出現頻度 $P_{R}$ を示す. 出現頻度の極大が, ほぼ時間平均再付着位置 $\overline{z_{R}} \quad(z / D=2.7)$ と一致していることがわかる. 一方, 前述のように, $\overline{z_{R}}$ より上流側に再付着するほどヌッセ ルト数の極大值が大きくなる. これが, 再付着位置 $\overline{z_{R}}$ に比べて熱伝達極大位置 $\overline{z_{h \max }}$ が上流側に存在する原 因となっている．なお，河村ら(河村他, 1988)の実験においても同様な結果が示されているが，本研究では瞬時熱 伝達率分布と瞬時再付着位置を同一位置・同一時刻において評価することに成功し，その結果を基に，再付着位 置と熱伝達極大位置の関係について明らかにすることができた.

\section{4. 結 言}

円管内オリフィス周囲のはく離・再付着を伴う流れ場において, 熱伝達の瞬時分布及びその非定常挙動を定量 的に測定した. さらに, 時々刻々と変化する熱伝達構造の移流速度を PIV 解析ソフトウェアを用いて評価した結 果，以下のことが明らかになった.

(1) PIV 解析で求めた移流速度の時間平均值は, 式(4)の相互相関法により求めた值とよく一致しており, 定量的 に妥当な值であることを確認した.

(2) 従来の研究と同様に, 時間平均熱伝達率の極大位置（本実験では $z / D=2.2 ）$ は, 時間平均再付着位置（本 実験では $z / D=2.7)$ よりも上流側に存在することを確認した.

（3）各瞬時再付着位置を抽出条件とし, 瞬時熱伝達率分布のアンサンブル平均を行った. その結果, アンサン ブル平均した熱伝達率分布は, 抽出条件とした瞬時再付着位置においてピーク值を示した. すなわち, 瞬時再付 着位置と瞬時熱伝達率極大位置は密接に関係していることを確認した. 
（4）アンサンブル平均の結果，抽出条件とした瞬時再付着位置が上流側に位置するほど熱伝達率の極大值が増 加する傾向があった，すなわち，上流側に再付着する流れほど伝熱促進への寄与度が高く，これが，時間平均熱 伝達率極大位置が時間平均再付着位置よりも上流側に存在する理由であることが示された.

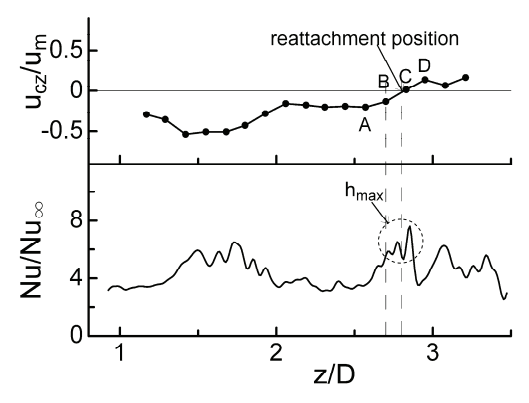

(a) Case $\mathrm{A}$

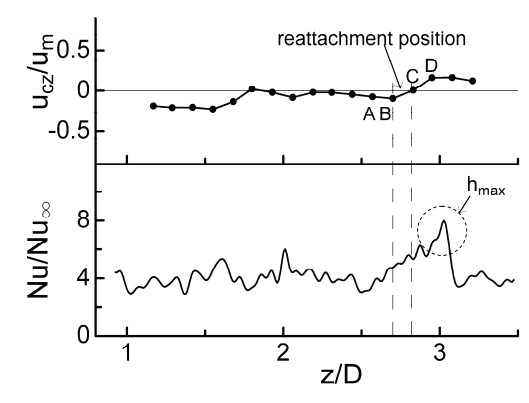

(b) Case B

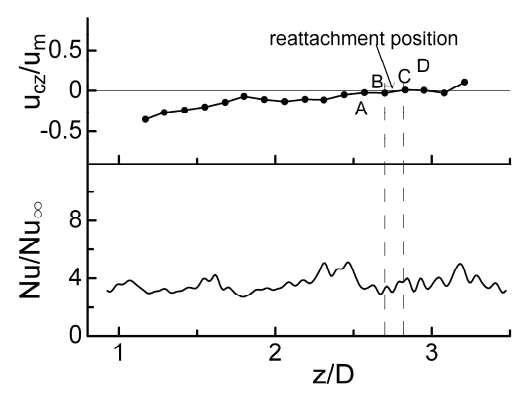

(c) Case $\mathrm{C}$

Fig. 10 Some examples of instantaneous convection velocity $u_{c z} / u_{m}$ and corresponding instantaneous Nusselt number distribution when the reattachment occurs at $z / D=2.70 \sim 2.82$. In the case of (a) (case A), the Nusselt number has a maximum at about reattachment position. In the case of (b) (case B), maximum heat transfer position does not coincide with reattachment position. And in the case of(c) (case C), there appears no remarkable peak in the Nusselt number distribution. Thus, the maximum heat transfer position does not necessarily coincide with the flow reattachment position.

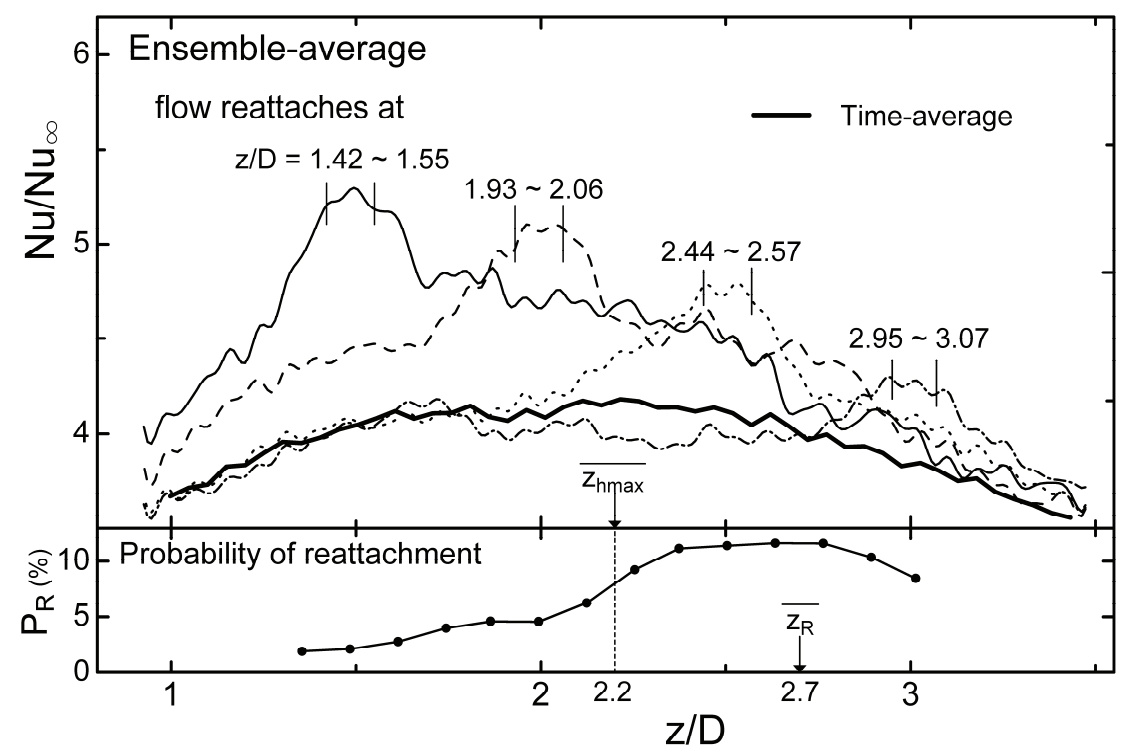

Fig. 11 Ensemble-averaged Nusselt number distribution on the condition that instantaneous reattachment appeared at specific streamwise positions. Probability of reattachment $P_{R}$ is also shown in the bottom, which has a maximum at around the time-averaged flow reattachment position. Ensemble-averaged Nusselt number shows a noticeable peak at the reattachment position of the extraction condition. This indicates that the instantaneous position of heat transfer maximum is closely related to the instantaneous position of the flow reattachment. Also, the peak value of the ensemble-averaged Nusselt number tends to increase toward upstream. This trend indicates that the flow reattachment at upstream contributes more significant to the heat transfer enhancement than that at downstream. This is the reason why the maximum position of the time-averaged heat transfer exists upstream of the time-averaged flow reattachment position. 


\section{文献}

Deotte, R. E., Morrison, G. L., Panak, D. L. and Nail, G. H., 3-D laser Doppler anemometry measurements of the axisymmetric flow field near an orifice plate, Flow Measurement and Instrumentation, Vol.2, No.2 (1991), pp.115-123.

Fujii, T., Fujii, M. and Honda, T., Theoretical and experimental studies of the free convection around a long horizontal thin wire in air, Proceedings of the 7th International Heat Transfer Conference (IHTC-7) (1982), pp.311-316.

Gnielinski, V., New equations for heat and mass transfer in turbulent pipe and channel flow, International Chemical Engineering, Vol.16, No.2 (1976), pp.359-367.

河村隆雄，田中誠司，熊田雅弥，馬淵幾夫，後向きステップ再付着領域の熱伝達の時空間的非定常特性，日本機械 学会論文集 B 編, Vol.54, No.504 (1988), pp.2114-2120.

木綿隆弘，歌野原陽一，中村晶，木村繁男，小松信義，山田紘司，菅原康裕，中道淳平，円管内オリフィス下流域に おける壁面せん断応力の時間平均之変動成分，日本機械学会論文集 B 編, Vol.79, No.799 (2013), pp.258-262.

Krall, K. M. and Sparrow, E. M., Turbulent heat transfer in the separated reattached, and redevelopment regions of a circular tube, Journal of Heat Transfer (1966), pp.131-136.

望月貞成, 伝熱促進技術と熱交換器 1. 伝熱促進技術の研究・開発動向 1.3 単相対流熱伝達, 冷凍, Vol.75, No.874 (2000), pp.662-666.

森康夫, 内田豊, 酒井宏, はく離再付着点近傍伝熱特性の時空間的微細構造解明の研究，日本機械学会論文集 $\mathrm{B}$ 編, Vol.52, No.481 (1986), pp.3353-3361.

中丸幹英, 津路正幾, 笠木伸英, 平田賢, ステップ後方剥離流の輸送機構に関する研究（第 2 報），第 17 回日本 伝熱シンポジウム講演論文集 (1980), pp.7-9.

Nakamura, H. and Yamada, S., Quantitative evaluation of spatio-temporal heat transfer to a turbulent air flow using a heated thin-foil, International Journal of Heat and Mass Transfer, Vol.64 (2013), pp.892-902.

Shiibara, N., Nakamura, H. and Yamada, S., Visualization of turbulent heat transfer to a water flow in a circular pipe using high-speed infrared thermography, Journal of Flow Visualization and Image Processing, Vol.20 (1-2) (2013), pp.65-81.

椎原尚輝，中村元，山田俊輔，高速度赤外線カメラを用いた円管内水流熱伝達の非定常測定，Thermal Science and Engineering, Vol.21, No.4 (2013), pp.105-113.

Shiibara, N., Nakamura, H. and Yamada, S., Quantitative measurement of heat transfer fluctuation in a pipe flow around an orifice plate using high-speed infrared thermography, Mechanical Engineering Journal, Vol.2, No.6 (2015), DOI: 10.1299/mej.15-00312.

鈴木健二郎，康倫明，杉本登志樹，佐藤俊，管内オリフィス下流の熱伝達，日本機械学会論文集 B 編，Vol.48， No.425 (1982), pp.132-140.

日本機械学会訳，アメリカ機械学会性能試験規約，計測機器及び試験装置に関する補則，第一部，計測の不確か さ, (1987).

日本機械学会編, 日本機械学会基準, 配管の高サイクル熱疲労に関する評価指針 (2003).

Vogel, J. C. and Eaton, J. K., Combined heat transfer and fluid dynamic measurements downstream of a backward-facing step, Transactions of the ASME, Journal of Heat Transfer, Vol.107 (1985), pp.922-929.

Yamada, S. and Nakamura, H., Spatial correlation of velocity and heat transfer downstream of a backward facing step using 2D-3C PIV and IR thermography, Proceedings of International Symposium On Turbulence and Shear Flow Phenomena (TSFP-9) (2015), 3D-4.

\section{References}

Deotte, R. E., Morrison, G. L., Panak, D. L. and Nail, G. H., 3-D laser Doppler anemometry measurements of the axisymmetric flow field near an orifice plate, Flow Measurement and Instrumentation, Vol.2, No.2 (1991), pp.115-123.

Fujii, T., Fujii, M. and Honda, T., Theoretical and experimental studies of the free convection around a long horizontal thin wire in air, Proceedings of the 7th International Heat Transfer Conference (IHTC-7) (1982), pp.311-316.

Gnielinski, V., New equations for heat and mass transfer in turbulent pipe and channel flow, International Chemical Engineering, Vol.16, No.2 (1976), pp.359-367.

Kawamura, T., Tanaka, S., Kumada, M. and Mabuchi, I., Time and spatial unsteady characteristics of heat transfer at the reattachment region of a backward-facing step, Transactions of the Japan Society of Mechanical Engineers, Series B, Vol.54, No.504 (1988), pp.2114-2120 (in Japanese).

Kiwata, T., Utanohara, Y., Nakamura, A., Kimura, S., Komatsu, N., Yamada, K., Sugawara, Y. and Nakamichi, J., 
Time-averaged and fluctuated wall shear stresses downstream from an orifice in a circular pipe, Transactions of the Japan Society of Mechanical Engineers, Series B, Vol.79, No.799 (2013), pp.258-262 (in Japanese).

Krall, K. M. and Sparrow, E. M., Turbulent heat transfer in the separated reattached, and redevelopment regions of a circular tube, Journal of Heat Transfer (1966), pp.131-136.

Mochizuki, S., Technique of heat transfer enhancement, heat exchanger 1. Trend of research and development of technique of the heat transfer enhancement 1.3 Single-phase forced convection, Refrigeration, Vol.75, No.874 (2000), pp.662-666 (in Japanese).

Mori, Y., Uchida, Y. and Sakai, K., A study of the time and spatial micro-structure of heat transfer performance near the reattachment point of separated flows, Transactions of the Japan Society of Mechanical Engineers, Series B, Vol.52, No.481 (1986), pp.3353-3361 (in Japanese).

Nakamaru, M., Tsuji, M., Kasagi, N. and Hirata, M., A study on the transport mechanism of separated flow behind a step, 2nd report, 17th National Heat Transfer Symposium of Japan (1980), pp.7-9 (in Japanese).

Nakamura, H. and Yamada, S., Quantitative evaluation of spatio-temporal heat transfer to a turbulent air flow using a heated thin-foil, International Journal of Heat and Mass Transfer, Vol.64 (2013), pp.892-902.

Shiibara, N., Nakamura, H. and Yamada, S., Visualization of turbulent heat transfer to a water flow in a circular pipe using high-speed infrared thermography, Journal of Flow Visualization and Image Processing, Vol.20 (1-2) (2013), pp.65-81.

Shiibara, N., Nakamura, H. and Yamada, S., Unsteady measurement of convective heat transfer to a water flow in a circular pipe using high-speed infrared thermograph, Thermal Science and Engineering, Vol.21, No.4 (2013), pp.105-113 (in Japanese).

Shiibara, N., Nakamura, H. and Yamada, S., Quantitative measurement of heat transfer fluctuation in a pipe flow around an orifice plate using high-speed infrared thermography, Mechanical Engineering Journal, Vol.2, No.6 (2015), DOI: 10.1299/mej.15-00312.

Suzuki, K., Kang, Y., Sugimoto, T. and Sato, T., Circular tube turbulent heat transfer in the downstream of an orifice, Transactions of the Japan Society of Mechanical Engineers, Series B, Vol.48, No.425 (1982), pp.132-140 (in Japanese).

The Japan Society of Mechanical Engineers translated, ASME Performance test codes, Supplement on instruments and apparatus, Part 1, Measurement uncertainty (1987) (in Japanese).

The Japan Society of Mechanical Engineers ed., JSME standard, Guideline for evaluation of high-cycle thermal fatigue of a pipe (2003) (in Japanese).

Vogel, J. C. and Eaton, J. K., Combined heat transfer and fluid dynamic measurements downstream of a backward-facing step, Transactions of the ASME, Journal of Heat Transfer, Vol.107 (1985), pp.922-929.

Yamada, S. and Nakamura, H., Spatial correlation of velocity and heat transfer downstream of a backward facing step using 2D-3C PIV and IR thermography, Proceedings of International Symposium On Turbulence and Shear Flow Phenomena (TSFP-9) (2015), 3D-4. 